Holocene Hydrological Changes Inferred from Alluvial Stream Entrenchment in North Tian Shan (Northwestern China)

Author(s): Blanche Poisson and Tean-Philippe Avouac

Source: The Journal of Geology, Vol. 112, No. 2 (March 2004), pp. 231-249

Published by: The University of Chicago Press

Stable URL: http://www.jstor.org/stable/10.1086/381659

Accessed: 10/01/2011 18:44

Your use of the JSTOR archive indicates your acceptance of JSTOR's Terms and Conditions of Use, available at http://www.jstor.org/page/info/about/policies/terms.jsp. JSTOR's Terms and Conditions of Use provides, in part, that unless you have obtained prior permission, you may not download an entire issue of a journal or multiple copies of articles, and you may use content in the JSTOR archive only for your personal, non-commercial use.

Please contact the publisher regarding any further use of this work. Publisher contact information may be obtained at http://www.jstor.org/action/showPublisher?publisherCode=ucpress.

Each copy of any part of a JSTOR transmission must contain the same copyright notice that appears on the screen or printed page of such transmission.

JSTOR is a not-for-profit service that helps scholars, researchers, and students discover, use, and build upon a wide range of content in a trusted digital archive. We use information technology and tools to increase productivity and facilitate new forms of scholarship. For more information about JSTOR, please contact support@jstor.org. 


\title{
Holocene Hydrological Changes Inferred from Alluvial Stream Entrenchment in North Tian Shan (Northwestern China)
}

\author{
Blanche Poisson ${ }^{1}$ and Jean-Philippe Avouac ${ }^{2}$ \\ Laboratoire de Géophysique, Commissariat à l'Energie Atomique, Bruyères-le-Châtel 91680, France \\ (e-mail: b.poisson@brgm.fr)
}

\begin{abstract}
A B S T R A C T
We analyze the possible contribution of climate change or tectonics on fluvial incision from the study of a case example along the northern flank of Tian Shan. The rivers that exit the high range fed large alluvial fans by the end of the last glacial period. They have since deeply entrenched the piedmont by as much as $300 \mathrm{~m}$. We have surveyed several terraces that were cut and abandoned during river entrenchment, providing information on intermediate positions of the riverbed during downcutting. They suggest a gradual decline in river slope during a major phase of incision throughout the Holocene. Tectonic uplift affects only a zone about $5 \mathrm{~km}$ wide, corresponding to a growing anticline, and is shown to account for about $10 \%$ of total incision. Incision was therefore most probably driven by climate change. From observed fluvial incision, we estimate the water discharge in excess of that needed to carry the sediments supplied by hillslope erosion in the headwaters. We used a model based on a transport-limited erosion law. The model predicts relaxation process with entrenchment in the upper reach, downstream progradation of the incision-sedimentation line, and a progressive decrease of river slope during incision consistent with our observations. According to this model, river slope might be used as a proxy for specific discharge and then for volumetric discharge, provided that an assumption is made about river width variations. We conclude that river incision in the study area has resulted from dynamic adjustment of the hydrological system to the settlement of wetter conditions in the early Holocene, when water discharge might have been about three times as high as at present. Then, a rather arid climate with enhanced seasonality has likely prevailed from the mid-Holocene ( 6 ka B.P.) until now.
\end{abstract}

Online enhancement: appendix.

\section{Introduction}

Rivers are commonly presumed to have a so-called graded profile and to keep it as a constant geometry during long periods, typically several thousands of years. Most river profile interpretations start from the point that a state of equilibrium has been reached, resulting from local hydrology and tectonics (e.g., Merritts et al. 1994; Demoulin 1998; Pazzaglia et al. 1998). However, as climate change or tectonic deformation proceeds, any stream needs some time to adjust itself to new external conditions, depending on its shift from associate new stable geometry (Snow and Slingerland 1990; Bull 1991; Vandenberghe 1995; Jones et al. 2000). Any 2003

Manuscript received July 16, 2002; accepted October 16, 1 Minières, Orléans, 45060 Cedex 2, France.

${ }^{2}$ Present address: California Institute of Technology, Pasadena, California 91125, U.S.A.; e-mail: avouac@gps.caltech.edu. active streambed may therefore be far from graded, and any paleostreambed should be interpreted in view of past hydrological dynamic adjustment. In addition, some authors (Phillips 1991) even claim that alluvial streams would not have any stable configuration, so that one can never predict what consequence any small perturbation may have on a fluvial system. However, similarities between the evolution of distant rivers in the same region incite us to presume that analogous external changes may cause analogous reactions in fluvial behavior, if main local characteristics (such as bedrock lithology, distribution of discharge, etc.) are similar. As an example, comparing Holocene alluvial chronologies through the United States, Knox (1984) found that most fluvial systems were affected by about the same sequence of episodes of incision and alluviation. It then may be possible to interpret the evolution of a fluvial system, and particularly of 
river profiles, in terms of geomorphic adjustment to paleohydrological changes (e.g., Bogaart and van Balen 2000; Jones et al. 2000).

Here we analyze a particular case example of an alluvial stream located in northern Tian Shan, central Asia (fig. 1). There, large rivers fed by high range catchments have incised 100-300-m-deep gorges into the piedmont alluvium, which was likely emplaced by the Late Pleistocene to Early Holocene (Avouac et al. 1993; Molnar et al. 1994). Although present local climate is semiarid (annual precipitation is $<300 \mathrm{~mm} / \mathrm{yr}$ in the piedmont), rivers were able to downcut at an average rate of $1-3 \mathrm{~cm} / \mathrm{yr}$ during the Holocene. Tectonic deformation is reasonably constrained from previous studies, so that prevailing climatic forcing on fluvial incision can easily be proved. In this article, we try to assess the paleohydrological changes that have forced this observed rapid and deep fluvial incision by taking river dynamics into account.

We particularly focus on river slope because it can be estimated from topographic measurements of fluvial terraces. River slope might then appear as a proxy for paleohydrology, leading to reconstruction of river specific discharge evolution, which is directly indicative of paleoclimatic conditions.

Hereafter, we briefly overview the geographic setting of the study area. Next, we describe the Holocene record of fluvial incision provided by a series of some well-preserved terraces along the Kuitun river. We show that Holocene river entrenchment must have resulted from climatic forcing. A simple model is then proposed to infer a varying hydrological context of the Kuitun river during the Holocene consistent with local paleoclimate records (e.g., Rhodes et al. 1996).

\section{Geographical Setting}

The Tian Shan is a 2000-km-long EW-trending range, with glaciated summits reaching elevations above $7000 \mathrm{~m}$, located in northwestern China. Regional climate is typically continental and semiarid, since it lies under the combined influence of the Westerlies, the cold air masses flowing from northern Asia, and the distant Asian monsoons (fig. 1). The range is still active and absorbs at least 6 $\mathrm{mm} / \mathrm{yr}$ of NS shortening at the longitude of the study area by overthrusting the Tarim basin to the

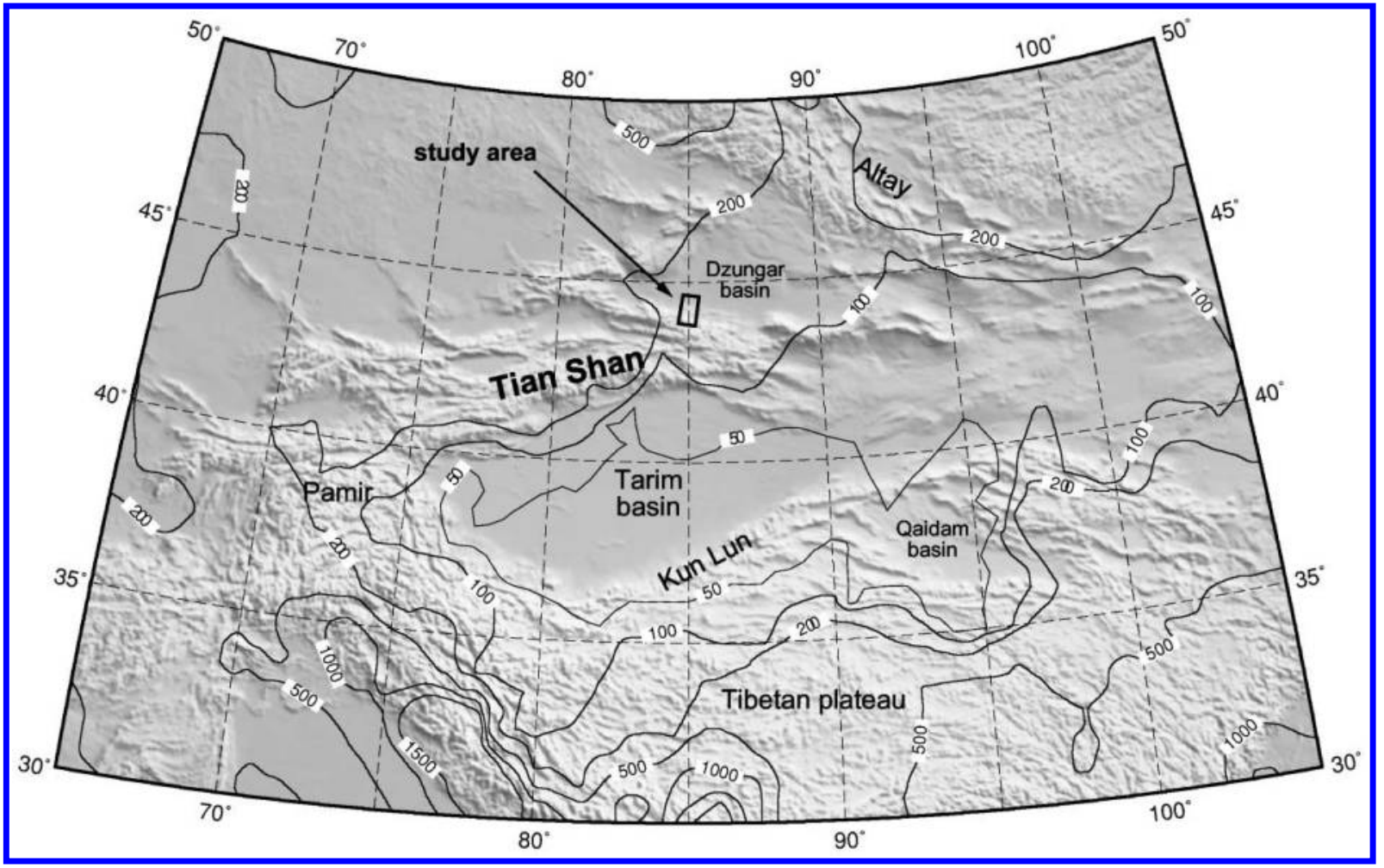

Figure 1. Geographic location of study area in central Asia. Contour lines indicate annual average precipitation (in $\mathrm{mm} / \mathrm{yr}$ ) over Asia from Legates and Willmott (1990). 


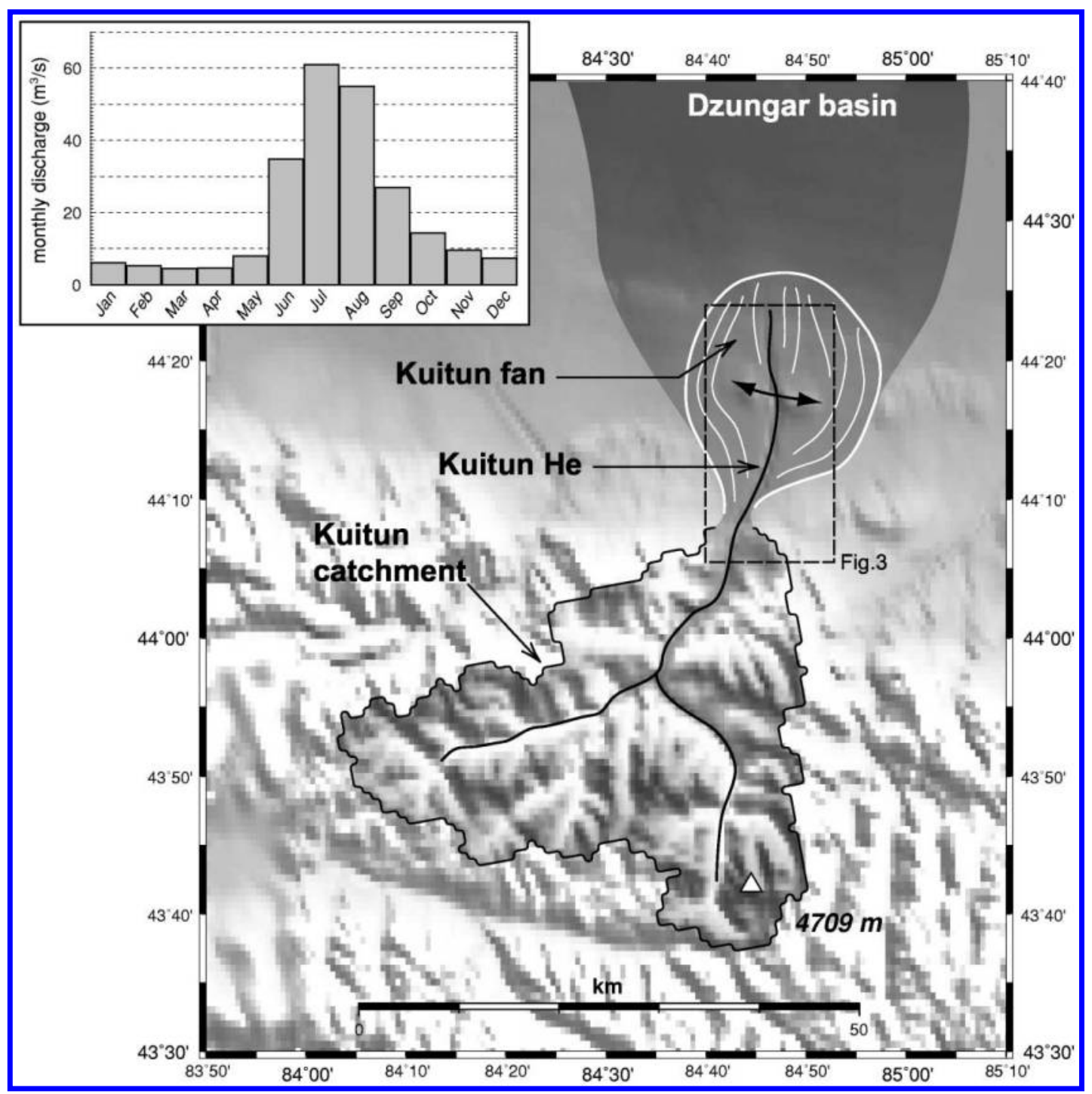

Figure 2. Location of Kuitun river, fan, and catchment on northern flank of east Tian Shan range and southern edge of Dzungar basin (GTOPO30 topography). Inset shows distribution of average water discharge over the year for Kuitun river; volumetric discharge remains much lower than its average during 9 mo, since the main flow occurs in summertime. Dashed box indicates location of area shown in left panel of figure 3.

south and the Dzungar basin to the north (Avouac et al. 1993; Reigber et al. 2001). We focus on the northern piedmont, where several parallel rows of active anticlines stretch EW, deforming recent fans and fluvial terraces.

As the range undergoes shortening and uplift, eroded material is transported by a transverse drainage toward the foreland basin. Similarities between main geomorphic objects along the piedmont seem to indicate that the whole region followed the same evolution at least through the last 10-100 kyr, with alternating periods of fan aggradation and river entrenchment (Molnar et al. 1994; Poisson 2002).
Among the streams flowing into the north Tian Shan piedmont, the Kuitun river seems to be particularly well suited to study fluvial incision (fig. 2). At the exit of the mountain front, the piedmont river reach is straight and deeply embanked. Farther north, it narrows as it cuts across the Dushanzi anticline (fig. 3). This fold grows over a southvergent thrust fault emerging at the surface and rooting in a 6-km-deep decollement (Molnar et al. 1994; Burchfiel et al. 1999). The Kuitun river discharge has an average annual value of $20 \mathrm{~m}^{3} / \mathrm{s}$ but appears to be very seasonal, since most of the discharge concentrates during summer months (fig. 2). 


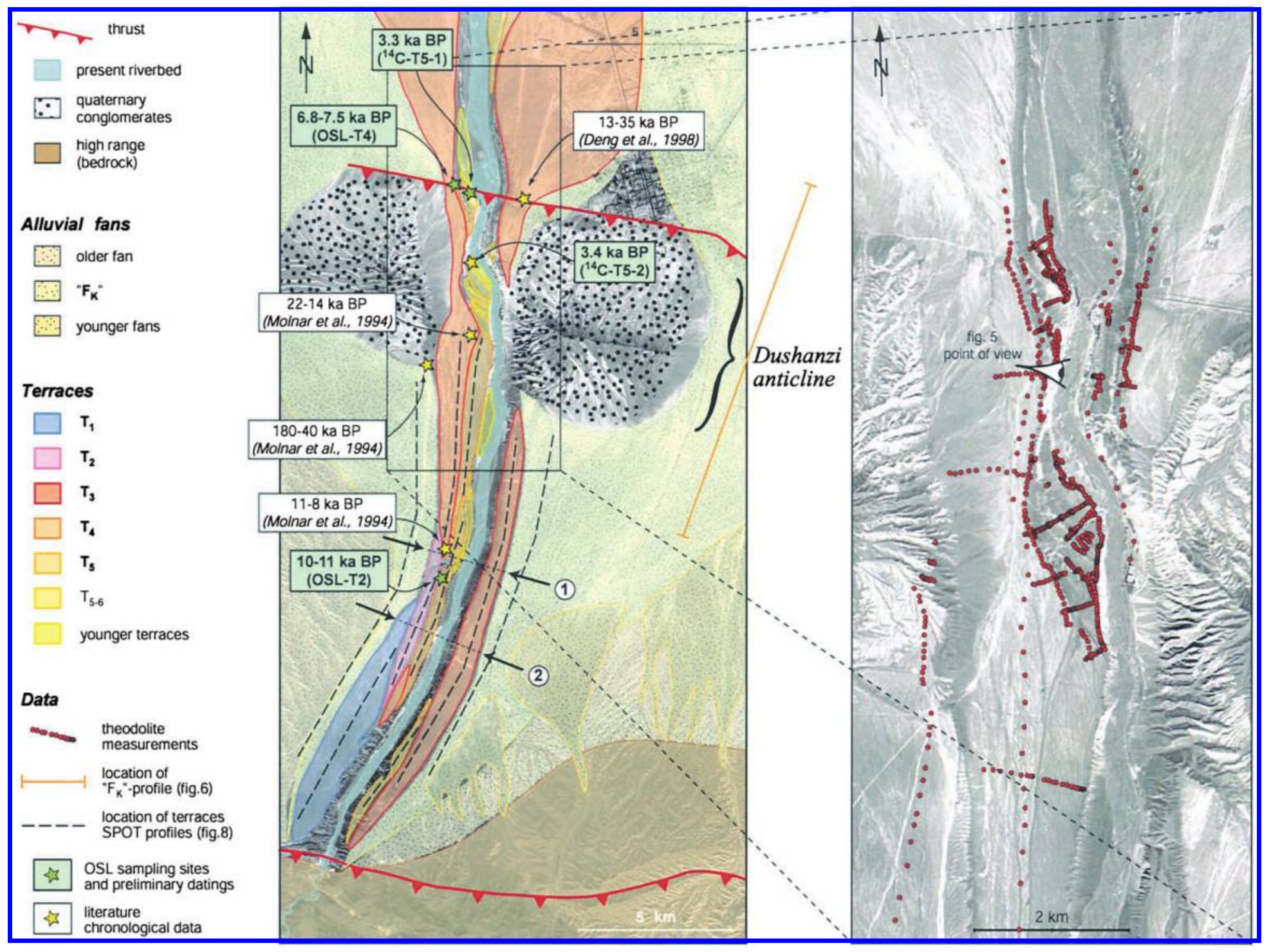

Figure 3. Geomorphic interpretation of study area superimposed on Landsat 7 (left) and SPOT (right) panchromatic images, and location of topographic field measurements. 


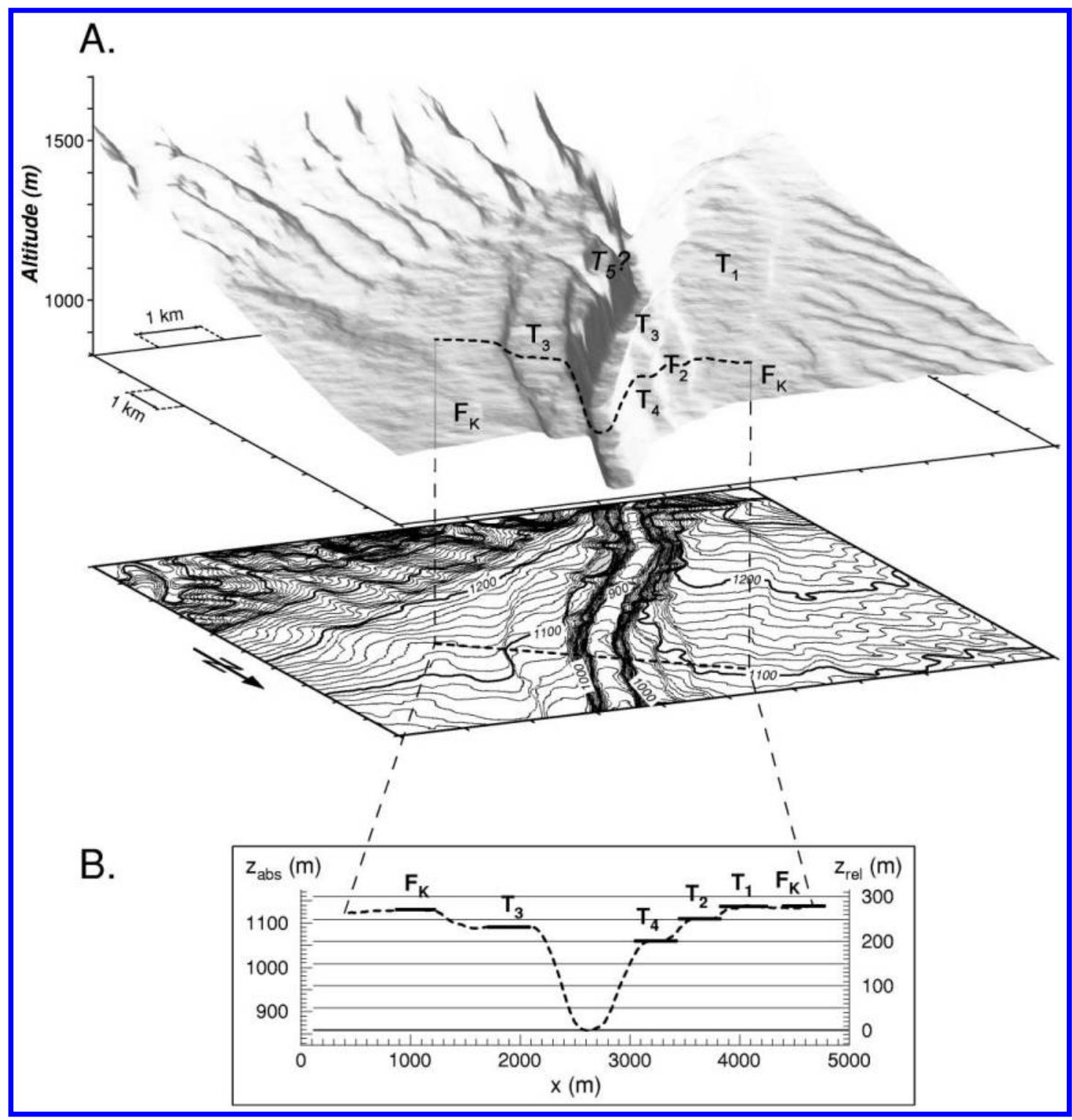

Figure 4. A, Three-dimensional view of the Kuitun river gorge and overhanging terraces near the fan apex and corresponding projected contour lines. The DEM was computed from SPOT stereographic images and then filtered (see details in the text). B, Example of topographic transverse profile extracted from the DEM.

We focused on two main characteristics of this river reach: (1) deep entrenchment in the youngest alluvial fans and underlying deposits and (2) measurable deformation through their folded terraces, allowing relative dating of the alluvial and fluvial surfaces.

\section{Description of Geomorphic Features around Kuitun River}

The study area was mapped from SPOT and Landsat 7 panchromatic images, with a spatial resolu- tion of 10 and $15 \mathrm{~m}$, respectively (fig. 3). We also used a digital elevation model (DEM) computed from a stereo pair of SPOT panchromatic images (fig. 4). Various fan deposits and fluvial terraces could be distinguished from their radiometry, texture, and elevation.

A large fan terrace $\left(\mathrm{F}_{\mathrm{K}}\right)$, fed from the Kuitun river, forms most of the alluvial pediment (figs. 2, 3). Few patches of older fan terrace are also preserved. Small tributaries emerging from the mountain front also emplaced small young fans that locally overlay $\mathrm{F}_{\mathrm{K}}$ deposits. Aggradation of Kuitun fan 
$\mathrm{F}_{\mathrm{K}}$ stopped when its feeding stream started entrenching the fan head. Several levels of fluvial terraces formed afterward, since the rivers entrenched first the recent fan deposits and then underlying Pliocene to Neogene loose conglomerates and sandstones. Such a geomorphic behavior is commonly observed in the foothills of active orogens (Ritter et al. 1995; Owen et al. 1997).

River terraces are preserved on both sides of the present river valley along the piedmont reach. Five major levels, labeled $T_{1}$ to $T_{5}$, are identified as obvious flat surfaces in the morphology. Level $T_{1}$ is only visible near the fan apex, where the river flows out from the range. Level $\mathrm{T}_{2}$ remnants appear somewhat lower downstream on the left edge, and following levels $T_{3}$ to $T_{5}$, relicts are present all along the studied reach from the range exit to the young active fan (north of anticline). The main terrace, $\mathrm{T}_{3}$ (fig. 5), is preserved about $15 \mathrm{~km}$ long on both edges and is about $2 \mathrm{~km}$ wide. Within the anticline, the $\mathrm{T}_{3}$ strath is covered by a $5-20$-m-thick dark gravel layer corresponding to aggraded sediments overlying the abandoned river bedload. We can observe several inset terraces $\left(T_{4}\right.$ and $\left.T_{5}\right)$ of the same kind beneath $\mathrm{T}_{3}$, but they show more modest remnants and most of them on one riverside at once. It is clear that, after $\mathrm{T}_{3}$ abandonment, the river could never again form a valley bottom wider than about $1 \mathrm{~km}$. Levels $\mathrm{T}_{3}$ and $\mathrm{T}_{4}$ can be easily distinguished south of Dushanzi anticline because of a clear difference in elevation $(20-30 \mathrm{~m})$. But they almost merge close to the fault, with $\mathrm{T}_{3}$ being only a few meters higher than $\mathrm{T}_{4}$. A succession of small terraces $\left(T_{5-6}\right)$ depicting a sort of staircase nests in the core of the anticline, straight above the only bend of the Kuitun piedmont reach. These curved $T_{5-6}$ surfaces are likely the result of a progressive downward migration of the stream bend. Since the river first turns to the left, the migration indicates that the little inset terraces are present only on the left edge.

We note that preservation of the observed inset terraces implies a decrease of the valley bottom width since abandonment of the first (preserved) one. We use the expression "apparent width" for the width of a preserved terrace tread, which results from a possible wandering of river braids. Past apparent width can be estimated from terrace width, which corresponds to the valley bottom width as the terrace was abandoned. The decreasing trend of apparent width could have been irregular with time, and intermediate terraces could have been formed and destroyed through successive episodes of shrinking and widening of the stream. But the general trend during river entrenchment consists of a clear decline of river apparent width. The hydrological regime at the time a terrace is formed depends in fact on the effective width, which may be very different from terrace width.

\section{Chronological Data}

Some chronological data are available from previous active tectonics studies (Molnar et al. 1994; Deng et al. 1996). Despite imprecision and sometimes approximative description, they provide some constraints on surface abandonment for some of the terraces. We also report some results from new optically stimulated luminescence (OSL) and ${ }^{14} \mathrm{C}$ analysis (table 1; data processing is detailed in Poisson 2002). Molnar et al. (1994) applied cosmogenic dating on quartz cobbles and obtained quite dispersed ages of exposure. Since their mapping of the terraces was not very precise, the exact location of their samples is difficult to assess. They must have been collected on $\mathrm{T}_{3}$, possibly $\mathrm{T}_{4}$. Ages range between 22 and 14 ka B.P. within the anticline and between 10.6 and $8.4 \mathrm{ka}$ B.P. some $5 \mathrm{~km}$ upstream (fig. 3). Deng et al. (1996) excavated a few trenches along several fault scarps in the piedmont in order to identify paleoseismic events and thereby sampled some carbonates for ${ }^{14} \mathrm{C}$ dating and some sediments for thermoluminescence (TL) dating. Fluvial layers within $\mathrm{T}_{3}$ on the right bank of the Kuitun river yielded ages between 13 and $35 \mathrm{ka}$ B.P., and one sample collected within the colluvium at the base of the fault scarp yielded an age of $7 \mathrm{ka}$ B.P. (fig. 3). These ages are difficult to interpret because the dated material is never precisely described (especially carbon-dated samples) and because of an apparent systematic discrepancy between TL and ${ }^{14} \mathrm{C}$ data. These ages suggest that the $\mathrm{T}_{3}$ (right) terrace was deposited before $13.3 \mathrm{kyr}$ and abandoned before $7 \mathrm{kyr}$. To obtain some tighter constraints, we collected some samples in colluvium, consisting of loess mixed with gravels from fluvial filling, on $\mathrm{T}_{2}$ (south of the anticline) and $\mathrm{T}_{4}$ (in anticline's core, a few hundred meters south of the fault; see fig. 3 ; table 1). They indicate that the $\mathrm{T}_{2}$ surface was abandoned around 11-10 ka B.P. (samples OSL-T2), whereas $\mathrm{T}_{4}$ was abandoned later, around 7.5-6.8 ka B.P. (samples OSL-T4). Pieces of charcoal from $T_{5}$ loess cover at two distinct sites give $\mathrm{T}_{5}$ age of abandonment around $3.3 \mathrm{ka}$ B.P. (samples C-T5).

\section{Qualitative Interpretation}

Our qualitative interpretation of the geomorphic record is the following: aggradation of the piedmont 
Table 1. Summary of Chronological Data Collected about Kuitun River Terraces

\begin{tabular}{|c|c|c|c|c|c|c|}
\hline \multirow[b]{2}{*}{ Name } & \multicolumn{2}{|c|}{ Location } & \multirow[b]{2}{*}{ Type of sample } & \multirow{2}{*}{$\begin{array}{l}\text { Depth } \\
\text { (m) }\end{array}$} & \multirow{2}{*}{$\begin{array}{l}\text { Size } \\
(\mu \mathrm{m})\end{array}$} & \multirow{2}{*}{$\begin{array}{c}\text { Age } \\
\text { (ka B.P.) }\end{array}$} \\
\hline & Longitude & Latitude & & & & \\
\hline OSL-T4-1 & $44^{\circ} 19^{\prime} 27^{\prime \prime}$ & $84^{\circ} 46^{\prime} 22^{\prime \prime}$ & Fluvial deposits (fine sand) & 1 & $63-80$ & $7.3 \pm 1$ \\
\hline OSL-T4-2 & $44^{\circ} 19^{\prime} 21^{\prime \prime}$ & $84^{\circ} 46^{\prime} 27^{\prime \prime}$ & Aeolian deposits (mixed loess) & 1 & $50-63$ & $6.8 \pm .5$ \\
\hline OSL-T4-3 & $44^{\circ} 19^{\prime} 20^{\prime \prime}$ & $84^{\circ} 46^{\prime} 28^{\prime \prime}$ & Colluvial deposits (mixed loess) & .5 & $50-63$ & $7.5 \pm 1$ \\
\hline OSL-T2-1 & $44^{\circ} 12^{\prime} 51^{\prime \prime}$ & $84^{\circ} 46^{\prime} 21^{\prime \prime}$ & Colluvial deposits (mixed loess) & 2 & $50-63$ & $10.0 \pm 1$ \\
\hline OSL-T2-2 & $44^{\circ} 12^{\prime} 41^{\prime \prime}$ & $84^{\circ} 46^{\prime} 03^{\prime \prime}$ & Aeolian deposits (homogeneous loess) & 3 & $50-63$ & $10.8 \pm 2$ \\
\hline $\mathrm{C}-\mathrm{T} 5-1$ & $44^{\circ} 19^{\prime} 17^{\prime \prime}$ & $84^{\circ} 46^{\prime} 44^{\prime \prime}$ & Charcoal in loess cover & & & $3.3 \pm .1$ \\
\hline C-T5-2 & $44^{\circ} 17^{\prime} 59^{\prime \prime}$ & $84^{\circ} 46^{\prime} 52^{\prime \prime}$ & Charcoal in loess cover & & & $3.4 \pm$ \\
\hline
\end{tabular}

Note. Samples with names beginning with OSL were dated through optically stimulated luminescence (depth of sampling and analyzed size fraction are reported). Samples with names beginning with $\mathrm{C}$ were radiocarbon dated (reported ages are calibrated with INTCAL 98).

fans probably took place because of massive sediment eviction from the high range catchment, during the glacial period because of glacial erosion and weathering, and at the deglaciation because of temporary very increased runoff. A more humid climate settled at the beginning of Holocene, which may have enhanced vegetation cover on high range hillslopes, thus reducing sediment production. When the stock of available sediments ran out, rivers flowing through the mountain front started incising the alluvial piedmont in the apex of fans. Fluvial transport capacity of these reaches was then saturated with the sediment yield provided by the loose alluvial substrate or from bank erosion. Accordingly, incision in the piedmont would reflect the water discharge in excess of that needed to carry the sediment load supplied from the mountain reaches upstream.

\section{Topographic Data}

Accurate topographic data were collected by theodolite measurements in the field along the major terrace levels within the Dushanzi anticline (fig. 3). Vertical precision is about $1 \mathrm{~cm}$, much less than the natural roughness of terraces treads. Other topographic data were available through a DEM computed from a SPOT stereo pair of images (fig. 4). Pixel size of the calculated DEM is $20 \mathrm{~m}$, and vertical noise can reach 5-10 m, but a Gaussian filtering reduces uncertainty and allows a rather good assessment of deformation and slope, considering long enough surfaces. All topographic data were registered to $1 / 100,000$ topographic maps.

Figure $6 \mathrm{~A}$ shows plots of theodolite longitudinal profiles of the fluvial terraces along the Kuitun river and a profile extracted from the DEM for Kuitun fan $\mathrm{F}_{\mathrm{K}}$ (fig. $6 \mathrm{~B}$ ). All these profiles are clearly warped, providing a way to estimate the ratio of their respective folding and hence of their relative ages. To do so, we assume that terrace longitudinal profiles were initially linear, such as the present riverbed or the fluvial terraces south of the anticline (fig. 6A), and we consider the residual topography as due to folding. Because all leveled surfaces have gentle slopes (from $1 \%$ to $2 \%$ ), subtracting the reconstructed initial profiles to real actual ones leads to an estimation of folding for each surface (fig. 6C). The pattern of warping obtained this way compares very well with the fold geometry documented from bedding dip angles measured about every $100 \mathrm{~m}$ along the Kuitun river (see section in fig. 6). Since the two profiles along $T_{3}$ and $F_{K}$ lie only $10 \mathrm{~km}$ apart (fig. 3), we may reasonably neglect lateral variation of fold geometry. Slip on the underlying thrust fault is probably stick-slip with recurring events about every 500-1000 yr on average (Avouac et al. 1993; Deng et al. 1996), but over a period longer than a few thousand years, we may assume a uniform fold growth. It follows that the ratio of the age of abandonment of $T_{3}$ and $F_{K}$ should be equal to the ratio of their amplitudes of folding. We deduce that the age of $\mathrm{T}_{3}$ should be around 0.8 that of $\mathrm{F}_{\mathrm{K}}$ (fig. 6C).

Comparison between structural section and terraces geometry makes it clear that tectonics is responsible for about $20 \mathrm{~m}$ of uplift within the Dushanzi anticline since $T_{3}$ abandonment (fig. 6C). There the Kuitun river has incised by about $150 \mathrm{~m}$ over this period. Two possibilities should be considered. One is that this entrenchment and the apparent tilt of the terraces was driven by deformation at the scale of the whole piedmont. In that case, the geometry of terraces might be taken to suggest that the whole piedmont wedge would shorten and thicken at the front of the advancing mountainous backstop (fig. 7). From a simple area balance, we find that the shortening rate required to produce $150 \mathrm{~m}$ of uplift at the location of the Dushanzi anticline should be of the order of $1 \mathrm{~km}$. This would correspond to $110 \mathrm{~mm} / \mathrm{yr}$ of shortening rate over the Holocene. This scenario can therefore 


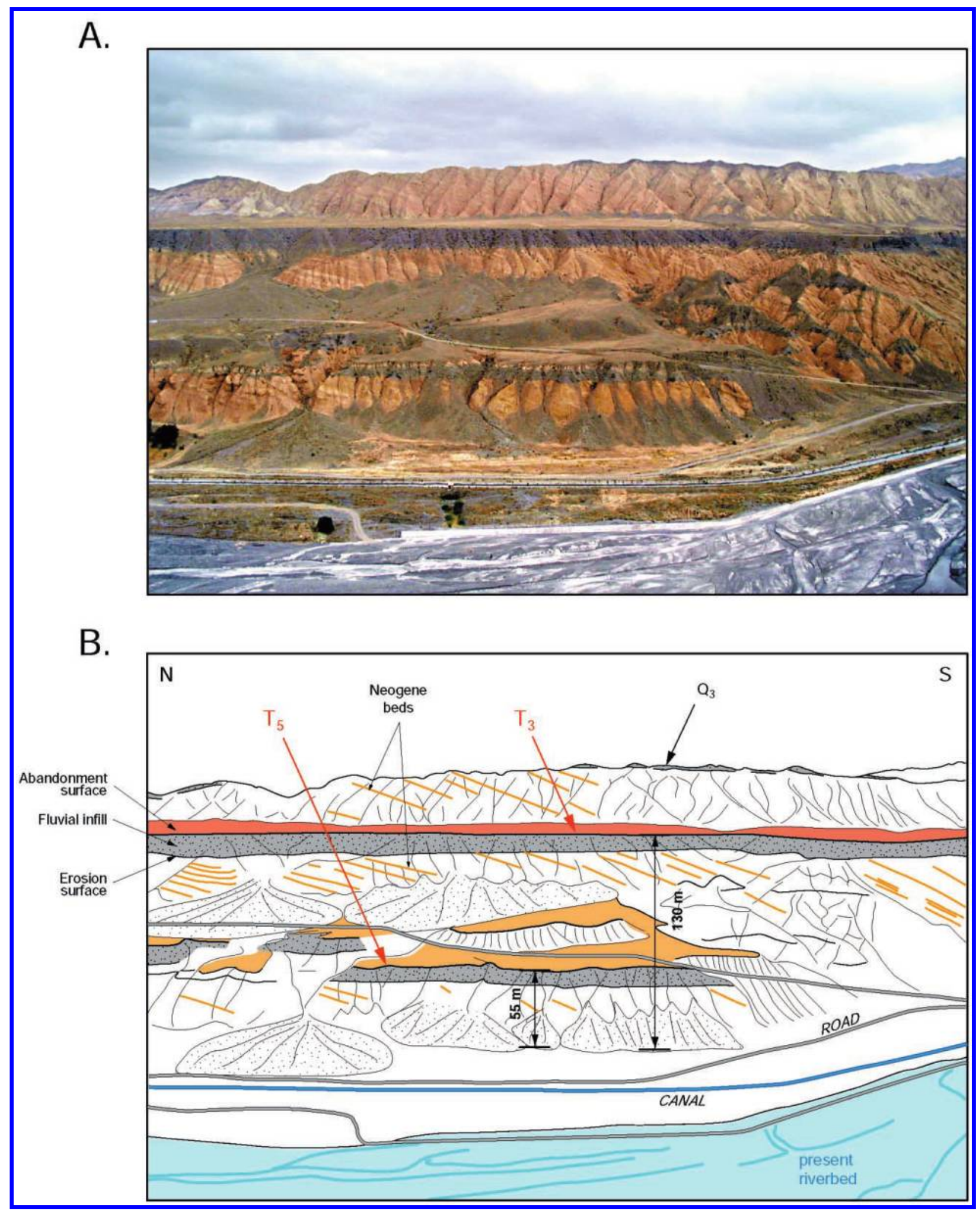

Figure 5. Photograph $(A)$ and interpretative sketch $(B)$ of Kuitun fluvial terraces in the core of Dushanzi anticline on Kuitun river right bank (view toward east). 


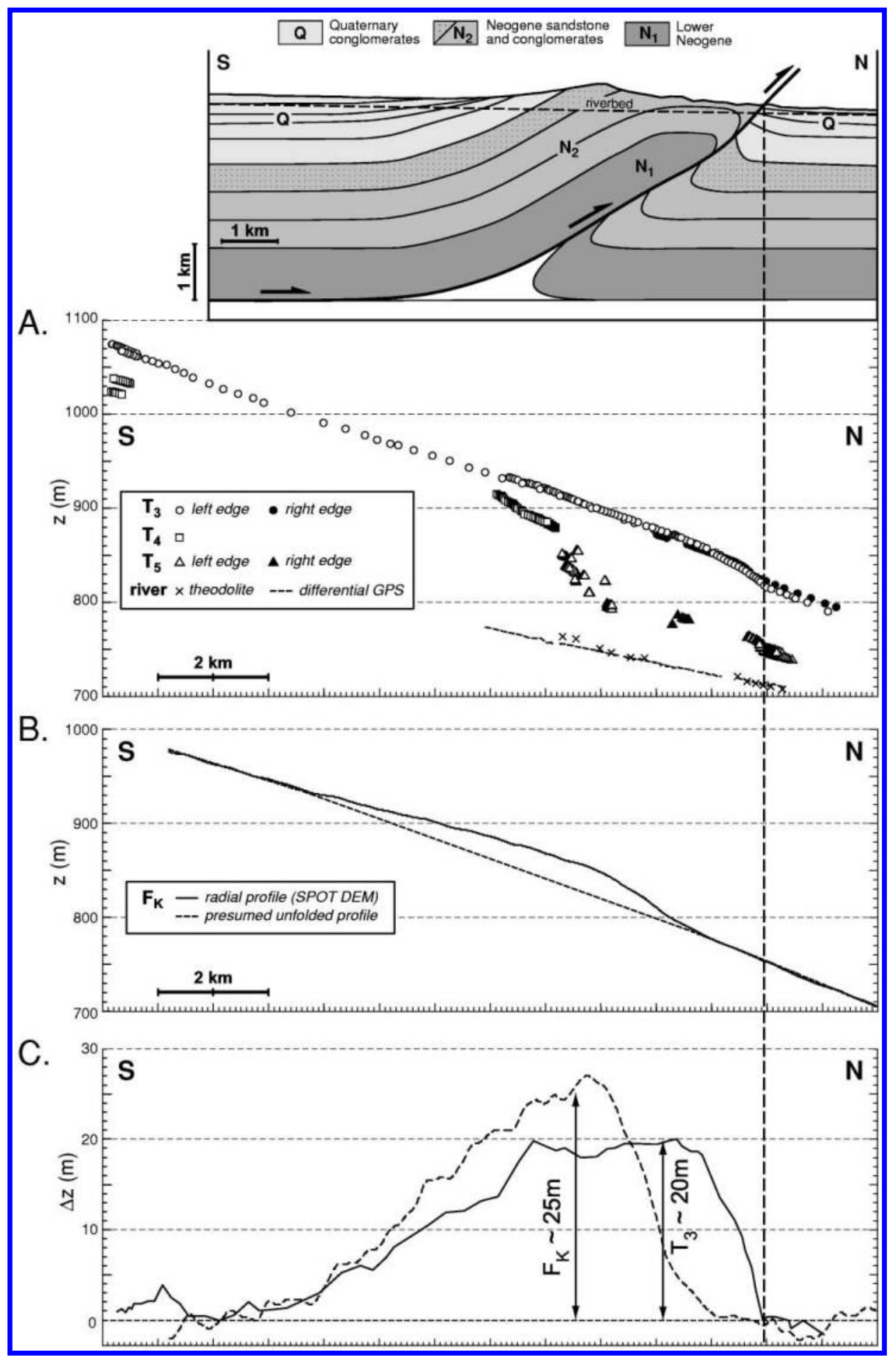

Figure 6. A, Kuitun terraces and stream profiles projected on a NS section. Circles and squares show theodolite measurements, while the riverbed line was measured by kinematic GPS. The geological section is derived from balancing structural measurements along the section (courtesy of S. Dominguez). B, Kuitun fan profile, as extracted from SPOT DEM. The profile is projected along a radial line according to fan geometry (see location in fig. 3); the dotted line shows the presumed unfolded profile. $C$, Folding profiles of $T_{3}$ and $F_{K}$ across the Dushanzi anticline obtained by removing presumed initial straight profiles. Note that the pattern of folding deduced from $T_{3}$ seems shifted to the north relative to that deduced from $\mathrm{F}_{\mathrm{K}}$. This shift might be due to a fold axis not purely perpendicular to the projection plane (NS) or to possible slight lateral variation of the fold geometry at depth. 


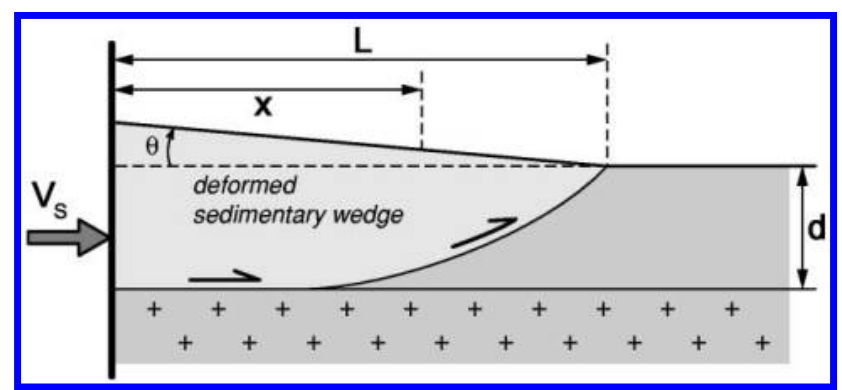

Figure 7. Testing of purely tectonic hypothesis. If the whole river downcutting corresponds to tectonic tilting of the piedmont wedge, the shortening needed to explain the observed amount of fluvial incision is estimated from following geometry: $L=30 \mathrm{~km}$ (piedmont length), $d=$ $6 \mathrm{~km}$ (decollement depth), $\tan (\theta)=2 \%$ (average slope of main fan); at $x=20 \mathrm{~km}$ (Dushanzi anticline), a simple area balance implies that an incision rate of $1.5 \mathrm{~cm} / \mathrm{yr}$ would require a shortening rate $\left(V_{\mathrm{s}}\right)$ of $11 \mathrm{~cm} / \mathrm{yr}$.

be easily discarded. However, we may contend that the only tectonic contribution is related to the growth of the Dushanzi anticline. Given the fold geometry at depth, we find that the warped terraces would indicate $5.2 \pm 0.4 \mathrm{~mm} / \mathrm{yr}$ of shortening rate over the Holocene. Such a rate would be consistent with the $6 \mathrm{~mm} / \mathrm{yr}$ of present shortening rate across the whole range measured from GPS. We therefore consider this scenario as the most realistic hypothesis. It follows that the Kuitun river entrenchment over the Holocene was mostly driven by hydrological processes. Tectonically driven incision amounted to at most $10 \%$ of the total entrenchment and was restricted to the Dushanzi anticline area.

\section{Slope Evolution and $S(z)$ Graphs}

Long topographic profiles were extracted from SPOT DEM along the fluvial terraces (fig. $8 A$ ). These profiles appear to be generally quite straight, with a tendency for the higher terraces to be steeper. Taking level $\mathrm{T}_{3}$ as an example, the top of the surface lies more than $250 \mathrm{~m}$ above the riverbed close to the range front, but $20 \mathrm{~km}$ farther downstream the offset is less than half, around $120 \mathrm{~m}$ where it goes out from the anticline. Just as discussed above, the downstream decrease in amount of incision cannot be due to tectonics. Then, river slope must have decreased during Holocene entrenchment.

Since direct chronological constraints on the timing of terrace formation and abandonment are generally loose, as in the case of our study, one may prefer to represent data without explicit chronol- ogy. At a given distance of the river mouth, we plot the slopes of the terraces versus their elevations (fig. 8B). Through this representation, we go around the lack of chronological data about some terraces. Whether the rate of entrenchment was constant during the whole erosive period or very irregular with a few intensive pulses, we can focus our attention on the relation between slope and amplitude of incision only. Our approach succeeds in evading the time problem but takes it into account implicitly through altitude, which is tightly connected with time by means of the incision rate.

Let us consider a few simple cases of river evolution to illustrate how $S(z)$ graphs may look like (fig. 9). For simplicity and to keep close to observations of the studied area, we consider only

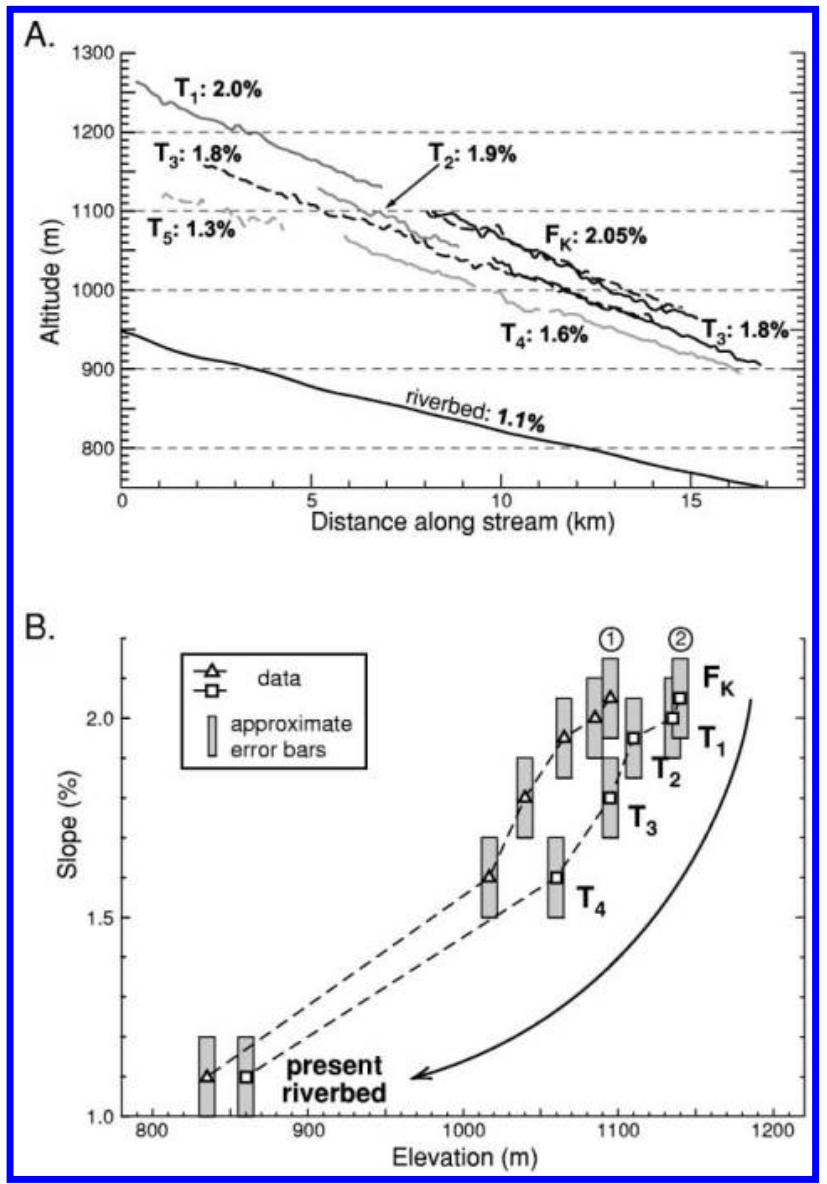

Figure 8. A, Long profiles of Kuitun terraces, as extracted from the SPOT DEM. Each profile was unwound along its own track in order to avoid aliasing in slope estimation. $B$, Plotting of terraces slopes versus elevation; each line shows $S$ and $z$ evolution at a fixed location of river profile. Points 1 and 2 of data collection are located in figure 3. 
A.

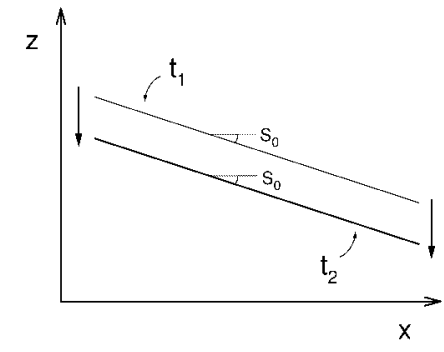

B.

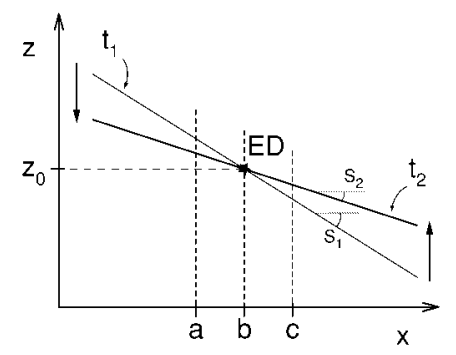

C.

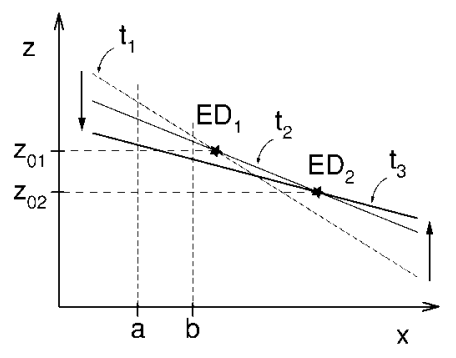

D.

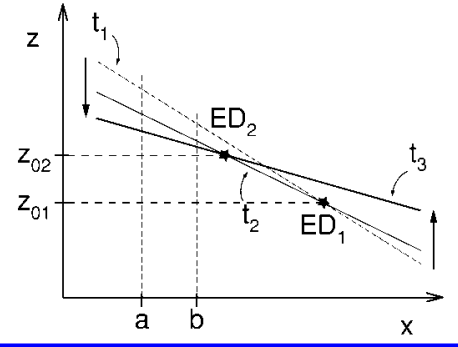

$\mathbf{S}(\mathbf{z})$
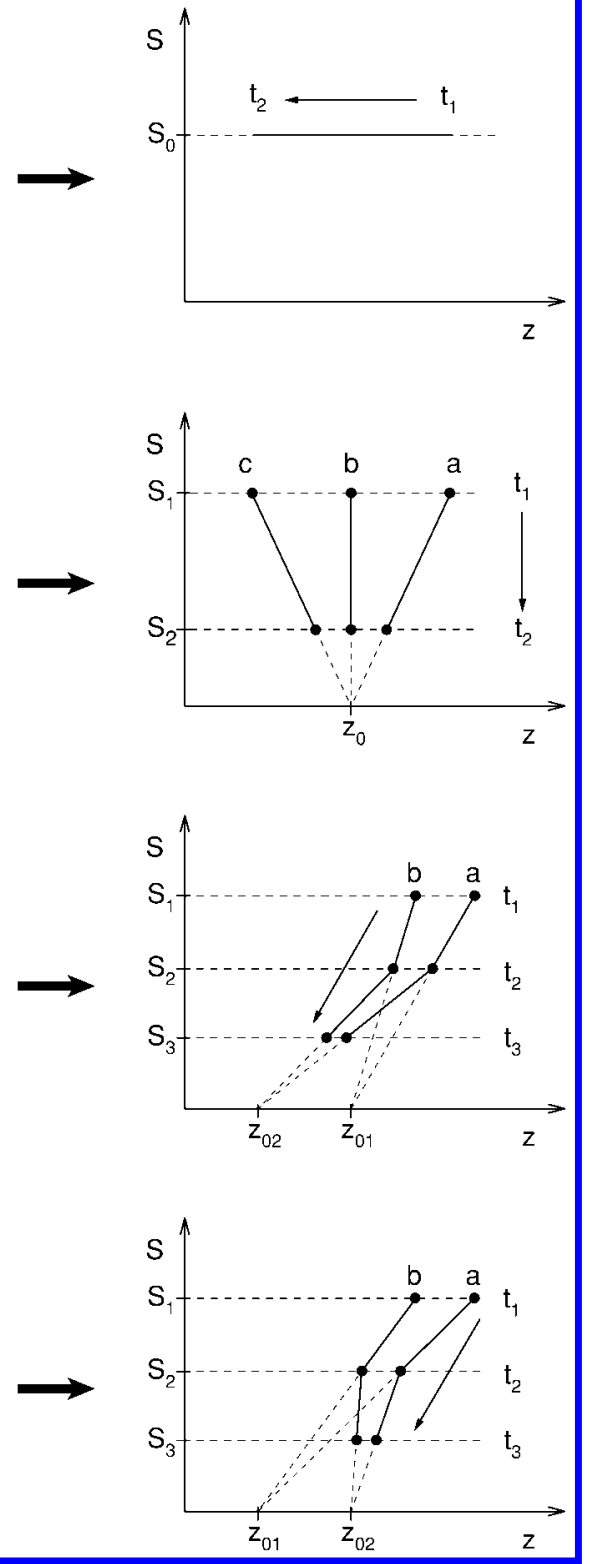

Figure 9. Representation of $S(z)$ plots for a few simple cases of river profile evolution (stars symbolize points of transition erosion/deposition). $A$, Incision rate has the same dynamics all along river profile; whatever happens, slope remains constant. $B$, River slope decreases homogeneously as the profile swivels on a fixed axis corresponding to the base level (star); above this point, riverbed subsides because of incision and $z$ decrease; below this point, stream rises up through aggradation. $C$, Two stages of tilting follow each other; because of base level lowering, $S(z)$ plots look convex. $D$, On the contrary, if base level rises up, $S(z)$ plots show concave shape.

straight profiles with decreasing slopes. The key parameter for river profile evolution is then the position of base level, which marks the transition between erosion and deposition (point $E D$ ). We focus our attention on the upper reach of profile, where only erosion occurs. If the $E D$ transition remains fixed through time, that is, at the same elevation $\left(z_{0}\right)$, the relation between slope and altitude is purely linear for each point of the profile (case $B$ ). If $E D$ moves downward through time (regression), then incision rate increases in relation to slope change, so that $S(z)$ curves become convex (case $C$ ). 
Table 2. Quantitative Data about Kuitun River, Fan, and Fluvial Terraces

\begin{tabular}{llccc}
\hline Surface & $S(\%)$ & $W_{\text {app }}(\mathrm{m})$ & $\Delta z(\mathrm{~m})$ & Age $($ ka B.P.) \\
\hline $\mathrm{F}_{\mathrm{K}}$ & 2.05 & $\ldots$ & 280 & $12.5-11$ \\
$\mathrm{~T}_{1}$ & 2 & 2700 & 275 & $?$ \\
$\mathrm{~T}_{2}$ & 1.95 & 2100 & 250 & $11-10$ \\
$\mathrm{~T}_{3}$ & 1.8 & 1950 & 235 & $10-7.5$ \\
$\mathrm{~T}_{4}$ & 1.6 & 1200 & 200 & $7.5-6.8$ \\
$\mathrm{~T}_{5}$ & 1.3 & 800 & $\ldots$ & 3.3 \\
Present riverbed & 1.1 & 400 & 0 & 0
\end{tabular}

Note. Morphological data are measured on SPOT DEM: slope $S$, apparent width $W$, and cumulative incision $\Delta z$ into each surface since its abandonment, estimated at $8 \mathrm{~km}$ from mountain front (point 2; see location in fig. 3). Proposed ages of surface abandonment are deduced from chronological constraints discussed in text (see fig. 3). Age of $T_{3}$ is bracketed by constraints on $\mathrm{T}_{2}$ and $\mathrm{T}_{4}$; age of $\mathrm{F}_{\mathrm{K}}$ is then estimated relative to $\mathrm{T}_{3}$ by using the ratio between their respective amounts of warping and assuming a constant uplift rate.

On the contrary, if ED moves upward (transgression), incision occurs above a rising limit, so that $S(z)$ curves appear to be concave (case $D)$.

Looking at Kuitun river data (fig. $8 B$ ), we see that starting from $T_{1}$ terrace, river slope first decreases "rapidly" in each graph, meaning that elevations of $\mathrm{T}_{1}, \mathrm{~T}_{2}$, and $\mathrm{T}_{3}$ are quite close, although associated slopes fall from $2.05 \%$ to $1.6 \%$. Because of a lack of paleoprofiles between $\mathrm{T}_{4}$ and the present riverbed, we cannot figure out how the river has evolved since $\mathrm{T}_{4}$ abandonment. However, one can imagine that the river did not undergo large changes afterward. Preservation of $\mathrm{T}_{4}$ relics on both edges indicate that river width was never larger than $\mathrm{T}_{4}$ width until now. The stream could only flow on a narrower bed, but if other terraces were formed, they must have been eroded. Besides, the little downstream remnant called $\mathrm{T}_{5}$ helps us to suppose that the Kuitun river entrenched the $T_{4}$ surface deeply without a strong modification of its slope. This ending (downstream) part of the graphs of figure 8 outlines the nonlinearity of the relation between slope and incision along time. Referring to typical examples shown in figure 9, Kuitun river behavior looks like the convex graph of case $C$, where a regressive event lets the $S(z)$ curve flatten toward low altitudes. Our rare and unevenly scattered data basically suggest a succession of two stages, with a second base level located lower than the first one. This downstream migration of deposition point is visible on satellite images (farther north than fig. 3), since the river arrives in the foreland basin. These remarks will help us to set up our incision model.

\section{Model}

In this section, we try to assess the hydrological changes that have forced the observed pattern of
Holocene fluvial incision. The river reach of interest begins at the transition between mountain front and the piedmont, where the stream emerges from stiff old bedrock into erodible Neogene sediments. On this piedmont reach, the Kuitun river is an alluvial river, so that erosion can be considered to be transport limited. The simulation starts from an initial profile similar to fan $F_{K}$ profile and shows how the river may have incised since the time of fan abandonment, taken at $12 \mathrm{ka}$ B.P. Available data used to constrain the model are summarized in table 2 .

Most common hydrological models are semiempirical or even purely phenomenological, so that they are based on power relations between the main variables, assuming some kind of steady state erosion (e.g., Howard 1982; Willgoose et al. 1991; Tucker and Bras 1998; Tucker and Whipple 2002). Here, we instead use a more physical approach based on Bagnold's formulation of bedload transport (Bagnold 1966), and we ignore any steady state hypothesis, since external forcing of incision is supposed to be unsteady.

We first compute the Rouse parameter, $P$, in order to assess whether the sediment load is mainly transported as bedload or as suspended load (e.g., Dade and Friend 1998):

$$
P=\frac{V_{\mathrm{s}}}{\kappa u^{*}}
$$

where $V_{\mathrm{s}}$ is the sedimentation rate and $u^{*}$ the friction velocity related to bed shear stress. Here, $P$ is much greater than unity (see appendix in the online edition of the Journal of Geology; it is also available from the Journal of Geology office on request), which is a criterion to neglect suspended load transport (Dade and Friend 1998). Present hydrological conditions are then consistent with a sediment load mainly consisting of bedload.

Balancing between the work available from fluid shear stress, $\tau$, and the work required to move sediment leads to

$$
e \cdot u \cdot\left(\tau-\tau_{\mathrm{c}}\right)=\left(\rho_{\mathrm{s}}-\rho\right) g \cdot q_{\mathrm{s}}
$$

(see notations in table 3). The efficiency coefficient, $e$, is the proportion of available energy that is really used for bedload transport (Bagnold 1966), and $\tau_{\mathrm{c}}$ is a critical shear stress. If shear stress $\tau$ is less than $\tau_{\mathrm{c}}$, then bedload cannot move. Relations between bed shear stress $\tau$, fluid velocity $u$, and the chosen 
Table 3. Notations Used in the Text

\begin{tabular}{|c|c|c|}
\hline Symbol & Definition & Dimension \\
\hline$C_{\mathrm{D}}$ & Drag coefficient & [1] \\
\hline$D$ & Average grain size & [L] \\
\hline e & Bagnold's efficiency coefficient & [1] \\
\hline$h$ & Water depth & {$[\mathrm{L}]$} \\
\hline$P$ & Rouse parameter & [1] \\
\hline$q$ & Specific water discharge & {$[\mathrm{L}]^{2} /[\mathrm{T}]$} \\
\hline$q_{\mathrm{s}}$ & Specific sediment flux & {$[\mathrm{L}]^{2} /[\mathrm{T}]$} \\
\hline$S$ & Local topographic slope & [1] \\
\hline$S_{\mathrm{c}}$ & Critical slope associated with $\tau_{\mathrm{c}}$ & [1] \\
\hline$u$ & Fluid velocity & {$[\mathrm{L}] /[\mathrm{T}]$} \\
\hline$u^{*}$ & Friction velocity (related to $\tau$ ) & {$[\mathrm{L}] /[\mathrm{T}]$} \\
\hline$W$ & Stream width & {$[\mathrm{L}]$} \\
\hline$\Delta$ & Relative excess density of sediment particles ${ }^{a}$ & {$[1]$} \\
\hline$\kappa$ & Von Karman constant & [1] \\
\hline$\rho_{\mathrm{s}}$ & Sediment density & {$[\mathrm{M}] /[\mathrm{L}]^{3}$} \\
\hline$\rho$ & Fluid density & {$[\mathrm{M}] /[\mathrm{L}]^{3}$} \\
\hline$\sigma$ & Sinuosity ${ }^{\mathrm{b}}$ & {$[\mathrm{M}] /[\mathrm{L}]^{3}$} \\
\hline$\tau$ & Bed shear stress & {$[\mathrm{M}] /[\mathrm{L}][\mathrm{T}]^{2}$} \\
\hline$\tau_{\mathrm{c}}$ & Critical shear stress for the onset of sediment motion & {$[\mathrm{M}] /[\mathrm{L}][\mathrm{T}]^{2}$} \\
\hline
\end{tabular}

Note. $[\mathrm{L}]$ is length; $[\mathrm{T}]$ is time; $[\mathrm{M}]$ is mass.

${ }^{\mathrm{a}}\left(\rho_{\mathrm{s}}-\rho\right) / \rho_{\mathrm{s}}$.

b Ratio of true length of active channel to apparent length of the river reach.

controlling variables, specific discharge $q$ and slope $S$, are

$$
\begin{cases}\tau & =\rho\left(u^{*}\right)^{2} \\ \left(u^{*}\right)^{2} & =C_{\mathrm{D}} u^{2}, \\ q & =u h .\end{cases}
$$

Combining these equations with the DarcyWeisbach formulation for friction factor (see appendix), we finally obtain the following expression for bedload:

$$
q_{\mathrm{s}}=\frac{e}{\Delta} \cdot \Phi^{1 / 3}\left(\Phi^{2 / 3}-\Phi_{\mathrm{c}}^{2 / 3}\right)
$$

where $\Phi=q S$.

The continuity equation for sediment simply relates vertical incision rate with horizontal gradient of sediment flux:

$$
\frac{d z}{d t}=\frac{d q_{\mathrm{s}}}{d x}
$$

where $x$ represents the distance along the river profile and $z$ is topographic elevation. Here, we consider a two-dimensional model (elevation $z$ vs. distance from range $x$ ), taking width variations into account through specific discharge $q$, which is the ratio of volumetric discharge to stream width. Since the piedmont reach of the Kuitun river entrenches a fan that has a divergent geometry, we presume that river discharge $(q)$ does not vary in the downstream direction $(x)$.
To account for tectonic deformation, we set up a $10-\mathrm{km}$-wide zone of $2 \mathrm{~mm} / \mathrm{yr}$ uplift, corresponding to Dushanzi anticline. However, simulations show that the river profile is not affected significantly by this deformation.

Kuitun river downcuts along almost $40 \mathrm{~km}$ into the fan $F_{K}$, which imposes a linear initial profile with a $2.05 \%$ slope and was deposited around 12 ka B.P., so that river evolution will be computed over a 12 -kyr-long period. Efficiency $e$ is taken to one-third, which is the value recommended in the turbulent case (Bagnold 1966). Hereafter we assume that the sediment yield at the outcome of the mountain front is negligible, $q_{\mathrm{s}}(\mathrm{x}=0)=0$, and we solve for the water discharge history $q$ needed to produce the observed incision. In fact, $q_{\mathrm{s}}(\mathrm{x}=0)$ is probably nonnull and may have varied with time. The values of $q$ obtained from the modeling with $q_{\mathrm{s}}(\mathrm{x}=0)=0$ might then be seen as some estimate of the water discharge in excess of that needed to carry the sediment yield $q_{\mathrm{s}}(x=0) \neq 0$. The transport capacity is not a linear function of $q$ because of the threshold $\Phi_{c}$, so that our hypothesis is only approximative. However, $q$ values obtained from our modeling provide a lower estimate of the real specific water discharge. Our study shows only the evolution of an alluvial reach into which the river runs with great available capacity. Results will then give quantitative estimation of hydrologic conditions as an inferior limit.

Since erosion occurs only when the shear stress exceeds the critical threshold, we must take into account only discharges fulfilling this requirement. 


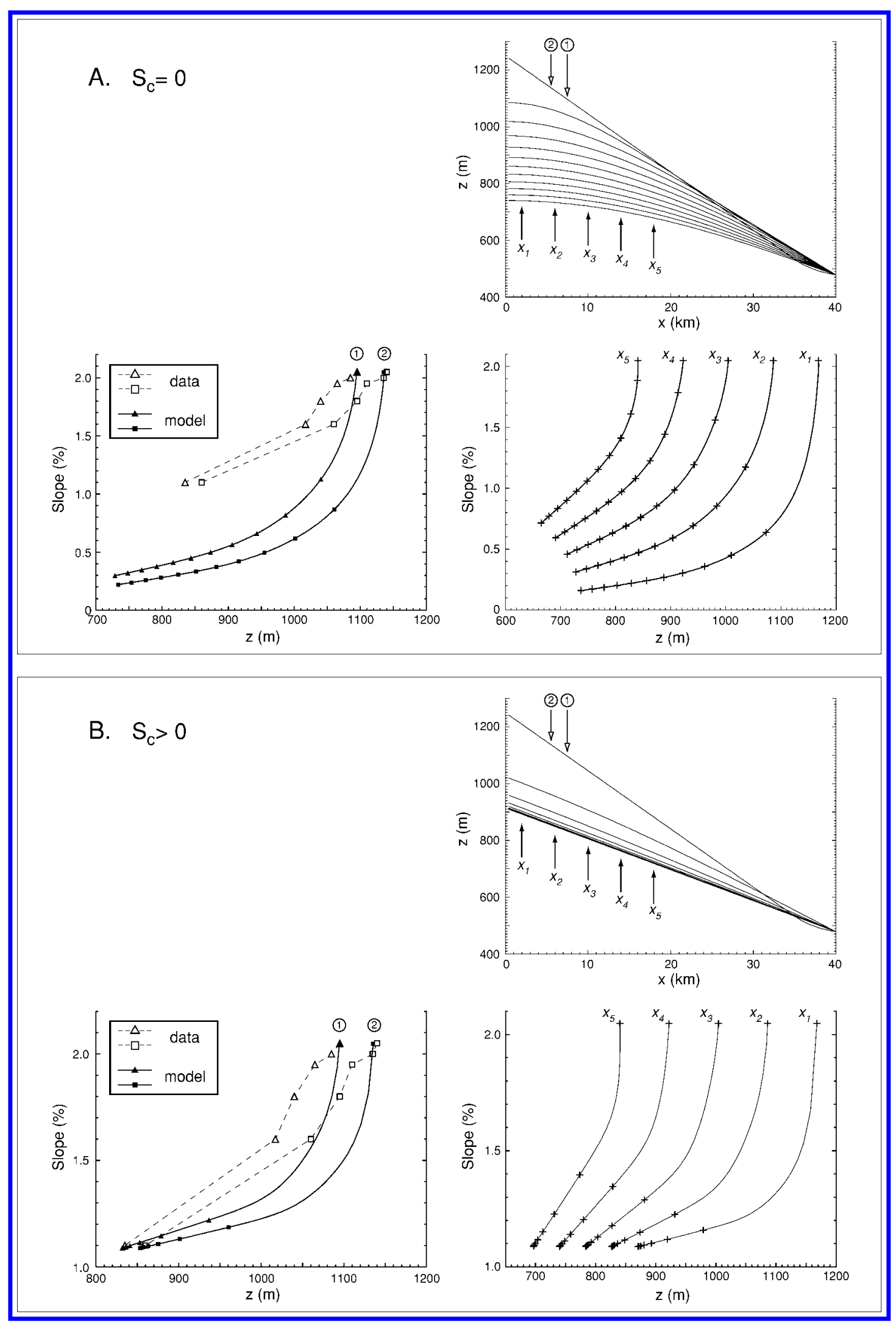


Using an average annual discharge would lead to an even bigger error since the threshold is high. We then introduce a weather index $i_{\mathrm{u}}$ (uniformity index) corresponding to the fraction of year during which discharge is large enough to overstep erosion threshold. The only available data about river hydrology is monthly average discharge for around 20 yr (fig. 2). This distribution gives an estimation of the $i_{\mathrm{u}}$ present value. High discharges occur from June to September because of higher summer precipitations. Discharge remains high during almost this whole period, allowing the Kuitun river to transport its bedload during 4 mo in a year. The $i_{\mathrm{u}}$ is then imposed to one-third for present time.

After each run, we plot slope versus elevation at several points along the river course and compare it with our data. Various tests were carried out to analyze the sensitivity of the model (fig. 10), then we tried to find the best set of parameters that can explain the data.

\section{Results and Discussion}

Whatever the hydrological parameters may be, we always obtain a decreasing trend in slope on the upstream reach of profile. When river comes into the piedmont flowing from the stiff high range, the stream power is high and erosion is strong. Then bedload increases and erosion power simultaneously decreases downward. In the lower part of the river, bedload is too high and material must be deposited (at the arrival in the Dzungar basin, strictly speaking). As a result, river slope can only decrease with time.

For a critical shear stress equal to 0 , the model simply consists of linear diffusion (because water discharge does not depend on distance in our case). So, calculated profiles become rapidly concave (fig. 10, case A). This effect disappears when we take into account a nonnull critical shear stress $\tau_{\mathrm{c}}$. Because of this threshold for the onset of sediment motion, the river profile constantly tends to an asymptotical profile depending on the value of $\tau_{\mathrm{c}}$ and then on hydrological conditions. The time needed to reach the asymptote is a function of the shift between the actual river slope $S$ and the critical slope $S_{\mathrm{c}}$ imposed by the threshold and the given discharge $q$ (from eqq. [3]):

$$
S_{\mathrm{c}} \sim \frac{\tau_{\mathrm{c}}^{3 / 2}}{q} .
$$

If $S \leq S_{\text {c, }}$ there is no more sediment transport. But if $S_{\mathrm{c}}$ is suddenly reduced to its half, it takes about $2000 \mathrm{yr}$ for the river to become roughly adjusted to the new conditions.

We can therefore act on $q, i_{\mathrm{u}}$ and $\Phi_{\mathrm{c}}=(q S)_{\mathrm{c}}$ $\left(\tau_{\mathrm{c}} \sim \Phi_{\mathrm{c}}^{2 / 3}\right)$ to fit $S(z)$ data. Since $\tau_{\mathrm{c}}$ is a sediment property, it stays constant along time, provided that the characteristics of the sediment charge change with time. Given that the terrace gravel is very similar on all terraces, this assumption seems reasonable. We take $S_{\mathrm{c}}=0.01$ as the critical slope associated with the present Kuitun river summer discharge (present characteristics being $S=0.01$ and $q \simeq 8 \times 10^{6} \mathrm{~m}^{2} / \mathrm{yr}$ ) to compute threshold value $\Phi_{\mathrm{c}}$. We then vary $q$ with time, keeping $\Phi_{c}$ constant (i.e., with $S_{\mathrm{c}}(t)$ constrained by $q(t)$ and constant $\left.\Phi_{\mathrm{c}}\right)$, in order to obtain $S$ values close to slope data. The weather uniformity index $i_{\mathrm{u}}$ does not have any influence on $S$ changes, but it controls the amplitude of incision, that is, the evolution of $z$.

There are too few data to set up a real inverse problem. However, we can propose hypothetical discharge evolutions that fit $S(z)$ data quite well (fig. 11).

Specific discharge is converted to volumetric discharge $Q$ through multiplication by stream effective width $W_{\text {eff }}$. Since only "peak discharge" is considered through the index $i_{\mathrm{u}}$, we also take it into account in our computation of whole discharge, assuming that when conditions are below the threshold of erosion, corresponding discharges have a negligible contribution to the mean annual discharge. We finally compute $Q$ as

$$
Q=q \cdot W_{\text {eff }} \cdot i_{\mathrm{u}} \cdot
$$

Figure 10. Examples of simple simulations of fluvial incision. The $z(x)$ profiles and $S(z)$ are plotted every $1000 \mathrm{yr}$ (from 12 ka B.P. to present); location of observations are indicated on the upper reach $\left(x_{1}\right.$ to $\left.x_{5}\right)$. Right graphs show river profile evolution, and left graphs compare results with data. $A, S_{\mathrm{c}}=0, q=5 \times 10^{5} \mathrm{~m}^{2} / \mathrm{yr}, i_{\mathrm{u}}=0.3$. The only fluvial processes is simple diffusion, so that topographic slope just tends toward 0 at each point and profile becomes more and more concave. $B, S_{\mathrm{c}}=0.01, q=3.6 \times 10^{6} \mathrm{~m}^{2} / \mathrm{yr}$, and $i_{\mathrm{u}}=0.3$ remain constant during $12,000 \mathrm{yr}$. Entrenchment is too rapid at beginning, although river profile tends to a plausible shape. This set of parameters would place $\mathrm{T}_{2}$ and $\mathrm{T}_{3}$ much lower in altitude than they are and with much smaller gradients. 


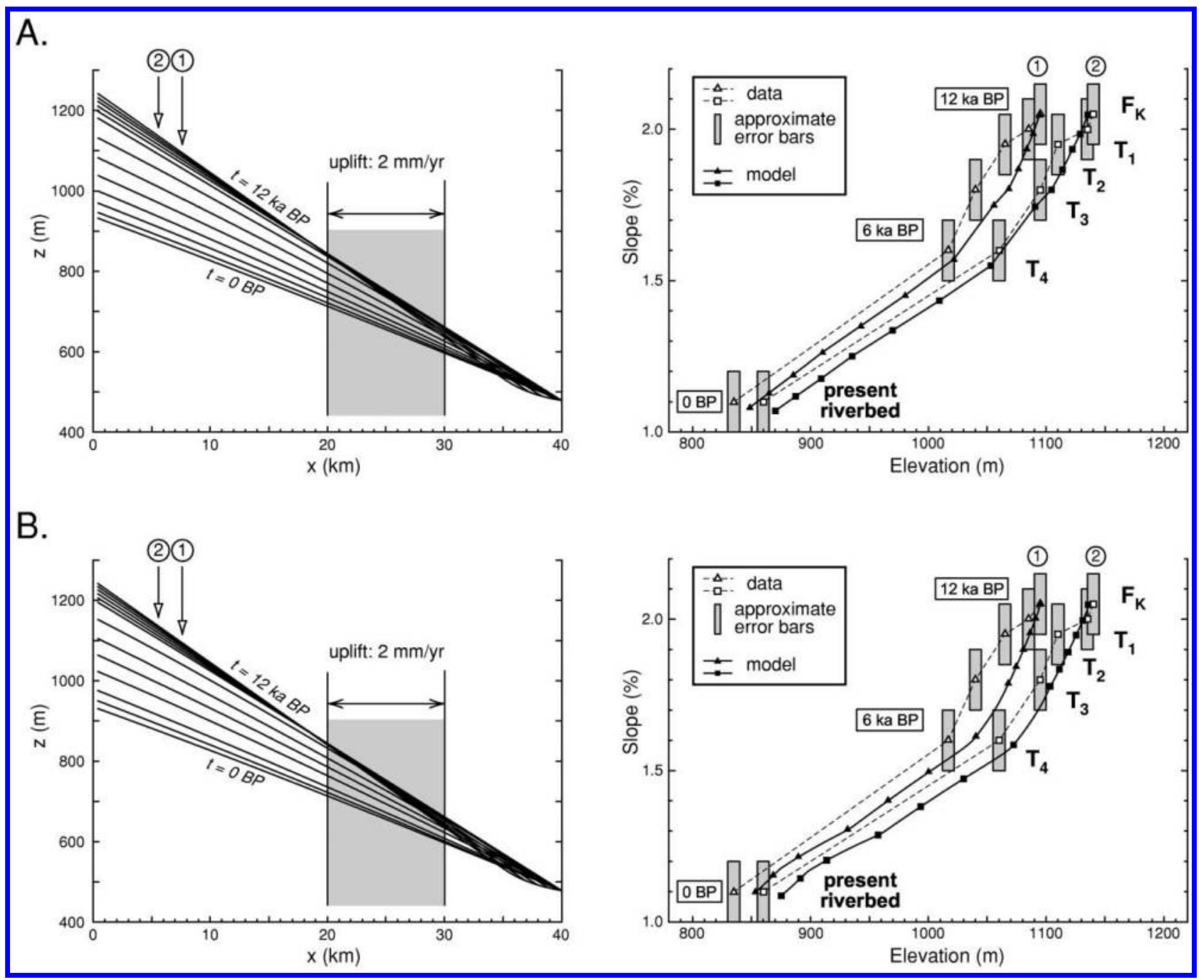

Figure 11. Example of simulations that correctly fit Kuitun river data (fig. 8). The $z(x)$ profiles are plotted every $1000 \mathrm{yr}$ from $12 \mathrm{ka}$ B.P. to present (left), and model output $S(z)$ is compared with Kuitun slope data at points 1 and $2($ right). Two extreme assumptions about effective stream width (active channel width) are tested: $(A)$ effective width proportional to observed terrace width and $(B)$ constant effective width and varying sinuosity (see parameters explanation in the text).

Since we do not know much about the evolution of the stream effective width, we have tested two extreme hypotheses (figs. 11, 12):

1. Effective width is assumed to be equal to a constant fraction of terrace width (figs. 11, 12; case A). It then varies abruptly at terrace abandonment, so that we deduce a discontinuous graph for volumetric discharge. In this case, $q$ decreases from $q_{0}=\Phi_{\mathrm{c}} / S_{0}$ at the beginning to present discharge at the end through successive linear trends. Because of large changes in stream width, volumetric discharge $Q$ strongly decreases from the beginning of Holocene until today. If we normalize reconstructed discharge at $12 \mathrm{ka}$ B.P. by the drainage area of the Kuitun river $\left(2000 \mathrm{~km}^{2}\right)$, we obtain a value that averages out at the annual precipitation rate over the whole basin. This value amounts to around $2800 \mathrm{~mm} / \mathrm{yr}$, which is unreasonably high in this very continental context. This is probably due to overestimated effective width when deduced from terraces width.

2. Effective width is assumed constant and equal to the $\sim 150 \mathrm{~m}$ width of the present river. In that case, the large terrace width would have resulted from lateral sweeping of the river channel. The terrace width would then be an indicator of the channel sinuosity. We take this sinuosity $\sigma$ into account, because a sinuosity higher than 1 entails a modified 

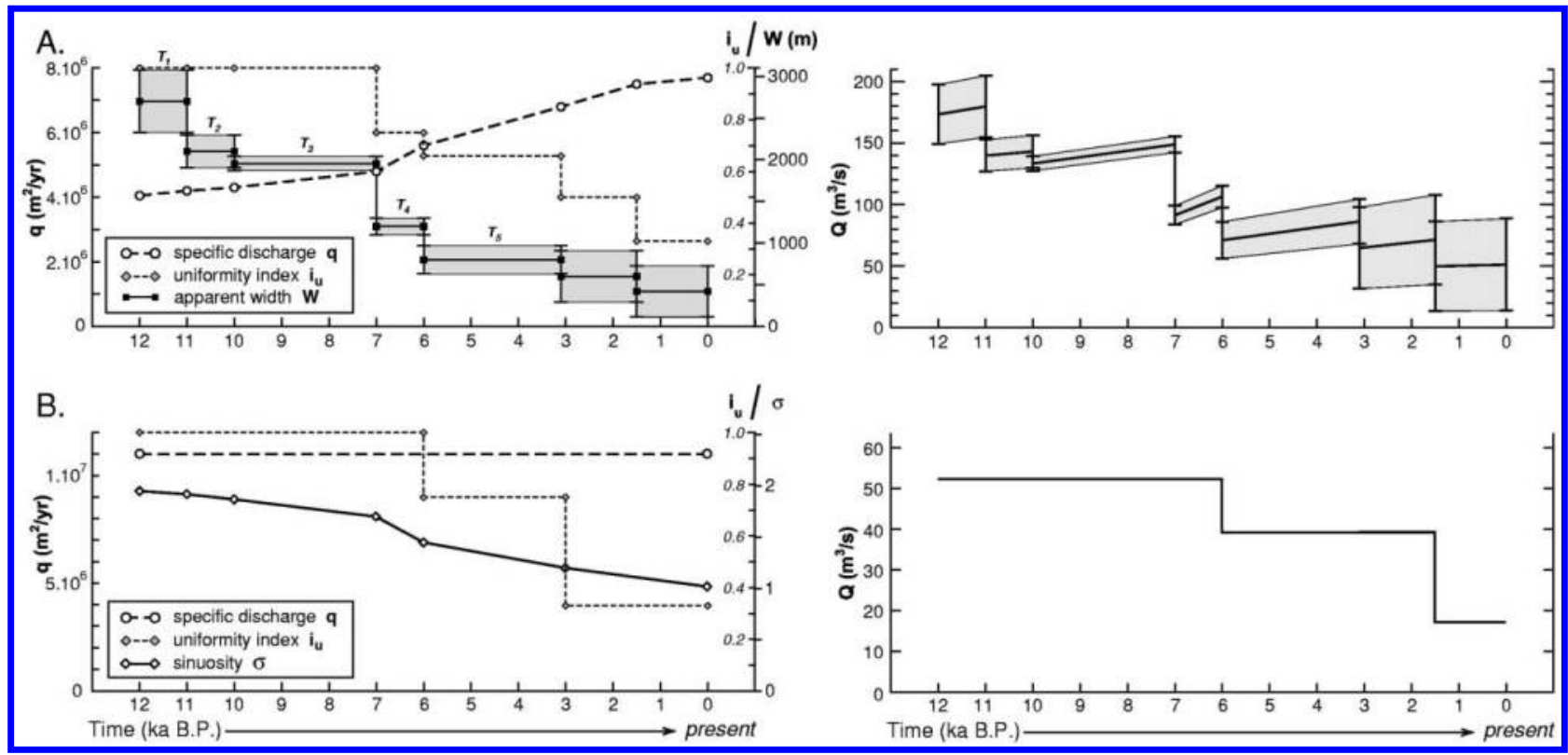

Figure 12. Best-fitting parameters $\left(q\right.$ and $\left.i_{\mathrm{u}}\right)$ leading to the modeled evolutions in the two extreme cases $(A, B)$ shown in figure 11. Volumetric discharge evolution is obtained from $q$ and $W\left(Q=q W i_{\mathrm{u}}\right)$, with error bars resulting from uncertainty about river width in $A$. A, Specific (erosive) discharge $q$ varies from $4 \times 10^{6} \mathrm{~m}^{2} / \mathrm{yr}^{2}$ at $t=0$ to $8 \times 10^{6} \mathrm{~m}^{2} / \mathrm{yr}$ at $t=12$ through successive linear trends. Weather index $i_{\mathrm{u}}$ (fraction of year during which the erosion threshold is exceeded) follows an evolution toward enhanced seasonality. Rough estimation of stream width changes from one terrace to another is made from SPOT imagery (fig. 3). $B$, As effective width remains constant, $q$ is also constant from $12 \mathrm{ka}$ B.P. until today. Sinuosity $\sigma$ decreases from around 2 to almost 1 at present, and $i_{\mathrm{u}}$ decreases at $6 \mathrm{ka}$ B.P. and $3 \mathrm{ka}$ B.P.

riverbed slope: $S=(1 / \sigma)(\partial z / \partial x)$, where $x$ is the direction of the main valley. Results are shown in figures 11 and $12(B)$. In this case, sinuosity changes lead to valid slope values, and two shifts of the uniformity index $i_{\mathrm{u}}$ are enough to induce observed incision. Volumetric discharge is divided by 3 between the Early Holocene and today. This ratio appears to be consistent with palaeohydrological information derived from palaeoshorelines of Aibi lake, which is the final outlet of the Kuitun river (Poisson 2002).

Although the second case seems more realistic, it should be noticed that both assumptions imply similar hydrological conclusions. Fitting our 7-6ka-B.P. terrace slope requires a major hydrologic change toward aridification. The weather index $i_{\mathrm{u}}$ is required to be quite high in the first phase, thereby strengthening the wet-to-dry transition at the mid-Holocene (fig. 12). At 6 ka B.P., $i_{\mathrm{u}}$ decreases just as $q$ increase (first case) or $\sigma$ decrease (second case) becomes more pronounced. This evolution could represent a rapid climatic change toward an arid context, since arid regions often show low volumetric discharges but with some rare high floods. Such a transition has been suggested to have a strong impact on incision rates (Molnar 2001) and may explain why the incision rate resulting from our model is so high between 6 and $3 \mathrm{ka}$ B.P. (see $z(x)$ profiles in fig. 11). After 3 ka B.P., $q$ decrease or $\sigma$ increase is maintained, but the slope is close to its asymptotical value $S_{\mathrm{c}}$, so that $S$ changes are weak until now. At the same time, $i_{\mathrm{u}}$ goes on decreasing to its present value.

Our results are finally in good agreement with current views of Holocene climate change in Asia. Early to mid-Holocene climate is known to have undergone a much stronger monsoonal influence than today in central Asia (Wei and Gasse 1999) because of global circulation change partly induced by orbital forcing. Ice records from the Tibetan Plateau (Thompson et al. 1989; Liu et al. 1998) as well as studies of China river systems (Porter et al. 1992; Yang et al. 2000) and most of lacustrine sedimentological records from China and surroundings (Jarvis 1993; Yang et al. 1995; Harrison et al. 1996) exhibit a humid phase lasting from about 11-10 ka B.P. until $\sim 6$ ka B.P. This humid climate likely resulted from a strengthened summer monsoonal circulation, reaching more inland places and higher latitudes than today (Wei and Gasse 1999). Next, a 
general trend of increasing aridity took place, lasting until today (Gu et al. 1993). In particular, Manas lake, which is located north of our study area, has recorded very wet conditions from 10 to $6 \mathrm{ka}$ B.P. (Rhodes et al. 1996). The second half of the Holocene was dominated by lake regression as a consequence of increased aridity. Furthermore, Aibi lake palaeoshorelines testify to a decrease of precipitation rate in a ratio of $2: 3$ between the midHolocene and today (Poisson 2002), which agrees with our second case. Our result then appears to be consistent with regional as well as local climate Holocene evolution.

\section{Conclusion}

The alluvial piedmont of northern Tian Shan has been deeply incised by the rivers since the beginning of the Holocene. Reconstruction of Holocene river paleoprofiles deduced from abandoned terraces allows some assessment of river slope changes. In our context, river slope decreased irregularly from fan slope to present-day riverbed slope. In a first phase from Early to mid-Holocene (12-6 ka B.P.), the river downcutted in a large valley, and its slope decreased quite rapidly since incision rate was moderate. In a second phase, the valley narrowed, and the river slope decreased more slowly while incision kept on. A model of alluvial stream erosion based on the Bagnold approach of sediment transport can reproduce the observed evolution of the river profile by introducing appropriate hydrological conditions. Two different assumptions were tested about the evolution of effective stream width, which is defined as the width of active channel. Effective width was first inferred to be proportional to observed terrace width. This hypothesis led to very large volumetric discharges for the Early Holocene, even likely immoderate. We then assumed a constant effective stream width, since active channel sweeping in the floodplain was considered through a varying sinuosity $>1$. This latter case led to a more plausible value of water discharge in the Early Holocene. Through this model, we finally infer hydrological regime of northern Tian Shan piedmont to have followed the general climatic trend of central Asia since the last deglaciation. We estimate that during the Early Holocene, Kuitun river discharge could have been three times the present one. Our survey shows that the profile of the Kuitun river has evolved continuously over the Holocene in response to changing hydrological conditions. Although it seems difficult to define a "graded" geometry for this kind of alluvial river, our model predicts that the river is never far from an equilibrium at which the river slope and specific discharge satisfy equation (6). It therefore allows us to retrieve past hydrological conditions from the estimate of the river paleoprofile as recorded by fluvial terraces, insofar as we test some assumptions about the evolution of effective stream width. This study points out the importance of considering both river slope and width to interpret fluvial behavior.

\section{A C K N O W LE D G M E N T S}

This research was funded by the Commissariat à l'Energie Atomique and by the Eclipse Centre National de la Recherche Scientifique program. We are grateful to N. Mercier for indispensable help in doing OSL analysis and for allowing data release before publication. We thank F. Métivier and S. Dominguez for fruitful discussions and help in the field. Two anonymous reviewers have provided most helpful comments and suggestions.

\section{REFERENCES C I T ED}

Avouac, J. P.; Tapponnier, P.; Bai, M.; You, Y.; and Wang, G. 1993. Active thrusting and folding along the northern Tien Shan and late Cenozoic rotation of the Tarim relative to Dzungaria and Kazakhstan. J. Geophys. Res. 98:6755-6804.

Bagnold, R. A. 1966. An approach to the sediment problem from general physics. U.S. Geol. Surv. Prof. Pap. 422-I, p. 231-291.

Bogaart, P. W., and van Balen, R. T. 2000. Numerical modeling of the response of alluvial rivers to Quaternary climate change. Global Planet. Change 27:147-163.

Bull, W. 1991. Geomorphic response to climate change. New York, Oxford University Press, 326 p.

Burchfiel, B. C.; Brown, E. T.; Qidong, D.; Xianyue, F.; Jun, L.; Molnar, P.; Jianbang, S.; Zhangming, W.; and
Huichuan, Y. 1999. Crustal shortening on the margins of the Tien Shan, Xinjiang, China. Int. Geol. Rev. 41: 665-700.

Dade, W. B., and Friend, P. F. 1998. Grain-size, sedimenttransport regime, and channel slope in alluvial rivers. J. Geol. 106:661-675.

Demoulin, A. 1998. Testing the tectonic significance of some parameters of longitudinal river profiles: the case of the Ardenne (Belgium, NW Europe). Geomorphology 24:189-208.

Deng, Q.; Zhang, P.; Xu, X.; Yang, X.; Peng, S.; and Feng, X. 1996. Paleoseismology of the northern piedmont of Tianshan mountains, northwestern China. J. Geophys. Res. 101(B3):5895-5920.

Gu, Z. Y.; Liu, J. Q.; Yuan, B. Y.; Liu, D. S.; Liu, R. M.; 
Liu, Y.; and Katsumi, Y. 1993. Monsoon variations of the Qinghai-Xizang Plateau during the last 12,000 years. Chin. Sci. Bull. 38:7577-7581.

Harrison, S. P.; Yu, G.; and Tarasov, P. E. 1996. Late Quaternary lake-level record from northern Eurasia. Quat. Res. 45:138-159.

Howard, A. D. 1982. Equilibrium and time scales in geomorphology: application to sand-bed alluvial streams. Earth Surface Process. Landforms 7:303-325.

Jarvis, D. I. 1993. Pollen evidence of changing Holocene monsoon climate in Sichuan Province, China. Quat. Res. 39:325-337.

Jones, S. J.; Frostick, L. E.; and Astin, T. R. 2000. Climatic and tectonic controls on fluvial incision and aggradation in the Spanish Pyrenees. J. Geol. Soc. Lond. 156: 761-769.

Knox, J. C. 1984. Responses of river systems to Holocene climates. In Wright, H. E., Jr., ed. Late-Quaternary environments of the United States. Vol. 2. The Holocene. London, Longman, p. 26-41.

Legates, D. R., and Willmott, C. J. 1990. Mean seasonal and spatial variability in gauge-corrected, global precipitation. Int. J. Climatol. 10:111-127.

Liu, K. B.; Yao, Z.; and Thompson, L. G. 1998. A pollen record of Holocene climatic changes from the Dunde ice cap, Qinghai-Tibetan Plateau. Geology 26:21352138.

Merritts, D. J.; Vincent, K. R.; and Wohl, E. E. 1994. Long river profiles, tectonism, and eustasy: a guide to interpreting fluvial terraces. J. Geophys. Res. 99(B7): 14,031-14,050.

Molnar, P. 2001. Climate change, flooding in arid environments, and erosion rates. Geology 29:1071-1074.

Molnar, P.; Brown, E. T.; Burchfiel, B. C.; Deng, Q.; Xianyue, F.; Jun, L.; Raisbeck, G. M.; et al. 1994. Quaternary climate change and the formation of river terraces across growing anticlines on the north flank of the Tien Shan, China. J. Geol. 102:583-602.

Owen, L. A.; Windley, B. F.; Cunningham, W. D.; Badamgarav, J.; and Dorjnamjaa, D. 1997. Quaternary alluvial fans in the Gobi of southern Mongolia: evidence for neotectonics and climate change. J. Quat. Sci. 12: 239-252.

Pazzaglia, F.; Gardner, T. W.; and Merritts, D. J. 1998. Bedrock fluvial incision and longitudinal profile development over geologic time scales determined by fluvial terraces. In Tinkler, K. J., and Wohl, E. E., eds. Rivers over rock: fluvial processes in bedrock channels. Am. Geophys. Union Geophys. Monogr. Ser. 107: 207-235.

Phillips, J. D. 1991. Multiple modes of adjustment in unstable river channel cross-sections. J. Hydrol. 123: 39-49.

Poisson, B. 2002. Impact du climat et de la tectonique sur l'évolution géomorphologique d'un piémont: ex- emple du piémont Nord du Tian Shan depuis la fin du Pléistocène. Ph.D. thesis, University of Paris XI.

Porter, S. C.; Zhisheng, A.; and Hongbo, Z. 1992. Cyclic Quaternary alluviation and terracing in a nonglaciated drainage basin on the north flank of the Qinling Shan, central China. Quat. Res. 38:157-169.

Reigber, C.; Michel, G. W.; Galas, R.; Angermann, D.; Klotz, J.; Chen, J. Y.; Papschev, A.; Arslanov, R.; Tzurkov, V. E.; and Ishanov, M. C. 2001. New space geodetic constraints on the distribution of deformation in central Asia. Earth Planet. Sci. Lett. 191:157-165.

Rhodes, T. E.; Gasse, F.; Ruifen, L.; Fontes, J. C.; Wei, K.; Bertrand, P.; Gibert, E.; et al. 1996. A Late PleistoceneHolocene lacustrine record from Lake Manas, Zunggar (northern Xinjiang, western China). Palaeogeogr. Palaeoclimatol. Palaeoecol. 120:105-121.

Ritter, J. B.; Miller, J. R.; Enzel, Y.; and Wells, S. G. 1995. Reconciling the roles of tectonism and climate in Quaternary alluvial fan evolution. Geology 23:3245-3248.

Rubey, W. W. 1933. Settling velocities of gravel, sand, and silt particles. Am. J. Sci. 25:325-338.

Snow, R. S., and Slingerland, R. L. 1990. Stream profile adjustment to crustal warping: nonlinear results from a simple model. Geology 98:699-708.

Thompson, L. G.; Mosley-Thompson, E.; Davis, M. E.; Bolzan, J.; Dai, J.; Gundestrup, N.; Yao, T.; Wu, X.; and Xie, Z. 1989. Holocene-Late Pleistocene climatic ice core records from Qinghai-Tibetan Plateau. Science 246:474-477.

Tucker, G. E., and Bras, R. L. 1998. Hillslope processes, drainage density, and landscape morphology. Water Resour. Res. 34:2751-2764.

Tucker, G. E., and Whipple, K. X. 2002. Topographic outcomes predicted by stream erosion models: sensitivity analysis and intermodel comparison. J. Geophys. Res. 107:2179-2194.

Vandenberghe, J. 1995. Timescales, climate and river development. Quat. Sci. Rev. 14:631-638.

Wei, K., and Gasse, F. 1999. Oxygen isotopes in lacustrine carbonates of western China revisited: implications for post glacial changes in summer monsoon circulation. Quat. Sci. Rev. 84:1315-1334.

Willgoose, G.; Bras, R. L.; and Rodriguez-Iturbe, I. 1991. A coupled channel network growth and hillslope evolution model. 1. Theory. Water Resour. Res. 27:16711684.

Yang, D. Y.; Yu, G.; Xie, Y. B.; Zhan, D. Z.; and Li, Z. J. 2000. Sedimentary records of large Holocene floods from the middle reaches of the Yellow River, China. Geomorphology 33:73-88.

Yang, W.; Spencer, R. J.; Roy Krouse, H.; Lowenstein, T. K.; and Casas, E. 1995. Stable isotopes of lake and fluid inclusion brines, Dabusun Lake, Qaidam Basin, western China: hydrology and paleoclimatology in arid environments. Palaeogeogr. Palaeoclimatol. Palaeoecol. 117:279-290. 